\title{
ANALISIS EFEKTIVITAS KEGIATAN DAN TINGKAT PENGALAMAN DALAM MENINGKATKAN KINERJA PEMASARAN TENAGA PENJUALAN DENGAN KOMPETENSI TEKNIK SEBAGAI VARIABEL INTERVENING PADA USAHA KECIL MENENGAH PAKAIAN JADI DI KOTA SEMARANG
}

\author{
Gita Sugiyarti \\ Fakultas Ekonomika dan Bisnis Universitas 17 Agustus 1945 (UNTAG) Semarang \\ Email: gitaayuaris@gmail.com
}

Received: April 2018; Accepted: May 2018; Available online: July 2018

\begin{abstract}
Abstrak
Tujuan penelitian ini untuk menguji dan menganalisis efektivitas kegiatan dan tingkat pengalaman menjual pada kompetensi teknik; serta efektivitas kegiatan dan kompetensi teknik pada kinerja pemasaran tenaga penjualan. Sampel penelitian ini sejumlah 100 responden pada Usaha Kecil Menengah pakaian jadi di Kota Semarang. Alat analisis menggunakan SEM dengan alat bantu AMOS versi 16. Temuan teoritis penelitian ini adalah ada pengaruh positif signifikan efektivitas kegiatan pada kompetensi teknik; ada pengaruh positif signifikan tingkat pengalaman menjual pada kompetensi teknik; ada pengaruh positif signifikan efektivitas kegiatan pada kinerja pemasaran tenaga penjualan; ada pengaruh positif signifikan kompetensi teknik pada kinerja pemasaran tenaga penjualan.
\end{abstract}

Kata Kunci: Efektivitas Kegiatan, Tingkat Pengalaman Menjual, Kompetensi Teknik, Kinerja Pemasaran Tenaga Penjualan

\begin{abstract}
The purpose of this study is to test and analyze the effectiveness of activities and level of selling experience on technical competence; as well as activity effectiveness and technical competence on marketing performance of sales force. The sample of this research is 100 respondents in Small and Medium Enterprises of apparel in Semarang City. Analyzer using SEM with AMOS Software version 16.0. The theoretical findings of this study were no significant positive effect on the effectiveness of activities on technical competence; there is a significant positive effect of the level of selling experience on technical competence; there is a significant positive effect of activity effectiveness on the sales force's marketing performance; there is a significant positive effect of technical competence on sales force sales performance.
\end{abstract}

Keywords: Activity Effectiveness, Level of Selling Experience, Technical Competence, Marketing Performance of Sales Force

How to Cite: Sugiyarti, G. (2018). Analisis Efektivitas Kegiatan dan Tingkat Pengalaman dalam Meningkatkan Kinerja Pemasaran Tenaga Penjualan dengan Kompetensi Teknik Sebagai Variabel Intervening pada Usaha Kecil Menengah Pakaian Jadi di Kota Semarang. Media Ekonomi dan Manajemen, 33(2), 132-140. 


\section{PENDAHULUAN}

Persaingan merupakan bagian yang tidak terlepaskan dari perusahaan, sebab adanya persaingan mendorong seorang pimpinan untuk menyusun strategi pemasaran secara tepat, sehingga memberikan keuntungan bagi perusahaan dari hasil penjualan. Salah satu strategi perusahaan sebagai pendukung keberhasilan adalah sumber daya manusia yang berkualitas. Tenaga penjualan adalah salah satu sumber daya manusia perusahaan yang memiliki peranan pencapaian tujuan.

Kinerja pemasaran yang efektif diilustrasikan sebagai evaluasi keseluruhan hasil penjualan perusahaan (Sugiyarti dan Ardyan, 2017). Kinerja pemasaran diukur dari indikator: volume penjualan total, pangsa pasar, biaya, kontribusi profit, dan kepuasan pelanggan (Ardyan dan Sugiyarti, 2018). Baldauf, et al. (2001) menjelaskan kualitas tenaga penjualan dan kinerja pemasaran adalah kunci sukses dari suatu keberhasilan perusahaan dan menjadi prioritas utama bagi pimpinan perusahaan. Agar perusahaan mempunyai tenaga penjual yang berkualitas maka bawahan harus mempunyai kompetensi teknik yang mendukung kinerjanya.

Kompetensi teknik menggambarkan kompetensi yang dimiliki oleh seorang penjual terkait dengan aktivitas transaksi barang atau jasa. Salah satu aspek kompetensi teknik adalah keahlian tenaga penjual pada kegiatan penjualan. Rentz, et al. (2002) dalam studinya menjelaskan: pertama, keahlian tenaga penjualan penting dalam kinerja pemasaran; kedua observasi pada area keahlian tenaga penjualan sangat terbatas; ketiga mengembangkan keahlian tenaga penjualan sebagai kerangka penelitian manajemen penjualan. Selain kompetensi teknik faktor yang terpenting dalam meningkatkan kinerja pemasaran tenaga penjualan adalah efektivitas kerja bagi tenaga penjual.

Tercapainya tujuan melalui penyelesaian pekerjaan sesuai dengan rencana disebut efektivitas kegiatan. Siagian (2008) keberhasilan dari sasaran yang ditetapkan. Apabila output kegiatan semakin mendekati sasaran, artinya efektivitasnya semakin baik.

Penelitian ini dilatarbelakangi oleh adanya riset gap yaitu adanya pengaruh positif antara efektivitas kegiatan dengan kinerja tenaga penjual (Sengupta, et al. 2000), hal ini menunjukkan bahwa aktivitas tenaga penjualan yang efektif merupakan bentuk rutinitas seorang tenaga penjualan dalam melaksanakan tugas dan tanggungjawabnya, sehingga tercapai kinerja pemasaran yang bersumber pada kemampuan dan keahlian yang dimiliki oleh organisasi. Di sisi lain Kristina (2006) menemukan bahwa pengaruh efektivitas kegiatan terhadap kinerja tenaga penjualan tidak signifikan, sebab peningkatan kinerja tenaga penjuala tidak hanya bersumber pada kemampuan dan keahlian saja akan tetapi harus belajar dari pengalaman.

\section{Perumusan Masalah}

Berdasar latar belakang masalah maka perumusan masalah sebagai berikut: Pertama, bagaimana pengaruh tingkat pengalaman menjual dan efektivitas kegiatan terhadap kompetensi teknik penjualan? Kedua, bagaimana pengaruh efektivitas kegiatan dan kompetensi teknik terhadap kinerja pemasaran tenaga penjualan?

\section{Tujuan Penelitian}

Tujuan penelitian ini untuk menguji dan menganalisis: satu, pengaruh tingkat pengalaman menjual dan efektivitas kegiatan terhadap kompetensi teknik tenaga penjualan; dua, pengaruh efektivitas kegiatan, kompetensi teknik terhadap kinerja pemasaran tenaga penjualan.

\section{TELAAH PUSTAKA Kinerja Pemasaran}

Kinerja pemasaran ialah suatu ukuran prestasi dari aktivitas pemasaran secara menyeluruh dari sebuah organisasi (Sugiyarti, 2015). Lamberti et al. (2010) 
menjelaskan kinerja pemasaran ialah faktor untuk mengukur dampak dari strategi yang diterapkan perusahaan. Kinerja pemasaran meliputi nilai penjualan, pertumbuhan penjualan, dan porsi pasar. Ferdinand (2000) kinerja pemasaran diukur melaui nilai penjualan yaitu return on invesment (ROI), return on asset (ROA). Ukuran tersebut dinilai sebagai ukuran agregatif melalui proses akuntansi dan keuangan, tetapi secara langsung tidak menggambarkan kegiatan manajemen pemasaran. Kinerja pemasaran diukur berdasarkan aktivitas aktivitas pemasaran antara lain volume penjualan dan pertumbuhan penjualan (Homburg et $a l$. , 2012). Begitu juga dengan pendapat Slater dan Naver (1994) bahwa keberhasilan kinerja pemasaran melalui pertumbuhan penjualan, volume penjualan dan return on asset setiap tahunnya.

\section{Kompetensi Teknik}

Pengetahuan khusus terkait dengan hubungan bisnis yang dimiliki tenaga penjualan disebut keahlian (Liu \& Leach, 2001). Keahlian seorang tenaga penjualan diketahui dari luasnya pengetahuan yang dimilikinya. Kemampuan seorang tenaga penjualan untuk memberikan solusi kepada pelanggan menunjukkan tingkat keahlian.

Rentz, et al. (2002) menjelaskan tiga keahlian yaitu interpersonal skill, salesmanship skill, dan technical skill. Interpersonal skill (keahlian inerpersonal) ialah keahlian seseorang menangani konflik. Ditekankan seorang sales mampu mengatasi konflik dalam proses menjual. Interpersonal yang dimiliki terlihat pada orang yang mempunyai pengaruh kuat dalam pembelian. Seseorang mempunyai tingkat interpersonal yang tinggi jika mampu memprediksi kesuksesan maupun kegagalan.

\section{Tingkat Pengalaman Menjual}

Tenaga penjualan yang berpengalaman memiliki pengalaman banyak pada berbagai situasi penjualan (Kohli et al., 1998). Mereka cepat menemukan intervensi pengawasan menyusahkan, mengurangi motivasi belajar. Tenaga penjualan yang tidak berpengalaman tidak memiliki pengalaman banyak menghadapi situasi penjualan beragam, sabar dalam pengawasan untuk mempengaruhi aktivitas sehari-hari. Tenaga penjualan berpengalaman konsen dan prestis dalam perusahaan. Umumnya sensitif sehingga diharapkan lebih keras memenuhi tujuantujuan aktivitas yang ditetapkan oleh para supervisor.

\section{Efektivitas Kegiatan Tenaga Penjualan}

Efektivitas kegiatan tenaga penjualan ditentukan faktor-faktor yang dikendalikan oleh individu tenaga penjual (Nuryakin dan Sugiyarti, 2018). Segmen pasar yang baik menyediakan kesempatan bagi tenaga penjualan mendapatkan keuntungan di lapangan. Rancangan wilayah penjualan yang efektif dapat meningkatkan efektivitas penjualan. Pimpinan harus tepat menentukan berapa jumlah pelanggan masing-masing tenaga penjualan, tanggung jawab produk (Baldauf, et al., 2001).

\section{Hubungan Antar Variabel

Hubungan Tingkat Pengalaman
Menjual dengan Kompetensi Teknik
Tenaga Penjualan

Tenaga penjualan berpengalaman memiliki pengetahuan dan pemahaman tentang situasi menjual dan mempunyai kemampuan mengerahkan ketrampilanketrampilan sesuai tugas-tugas penjualan (Kohli et al., 1998). Aspek yang paling penting adalah pencapaian pada tujuantujuan kinerja. Tenaga penjualan yang berpengalaman lebih potensial untuk merasa malu jika dianggap tidak mampu, sehingga selalu berusaha meningkatkan kinerjanya.

Kompetensi tehnik penjualan adalah suatu keahlian yang dimiliki oleh tenaga penjual (Liu dan Leach, 2001). Dengan pengalaman penjualan berarti seorang tenaga penjual mempunyai kompetensi teknik yang cukup baik untuk melakukan 
penjualan. Atas dasar uraian di atas dapat diajukan hipotesis pertama:

H1: Tingkat pengalaman menjual berpengaruh positip terhadap kompetensi teknik penjualan.

\section{Hubungan Efektivitas Kegiatan Ter- hadap Kompetensi Teknik Penjualan}

Dari kaca mata manajerial bahwa aspek keahlian adalah penting untuk efektivitas kinerja tenaga penjualan. Keahlian tenaga penjualan dalam aktivitas penjualan merupakan atribut dari tenaga penjualan (Liu dan Leach, 2001). Baik buruknya kinerja seorang tenaga penjualan terletak pada kemampuan seseorang tenaga penjualan dalam menjalankan aktivitas penjualan secara efektif. Berdasarkan uraian di atas diajukan hipotesis kedua:

$\mathrm{H} 2$ : Efektivitas kegiatan berpengaruh positif terhadap Kompetensi teknik penjualan

\section{Hubungan Efektivitas Kegiatan Ter- hadap Kinerja Pemasaran Tenaga Penjual}

Baldauf, et al. (2001) mengatakan keahlian tenaga penjualan menyebabkan kinerja tenaga penjualan meningkat, sesuai dengan harapan yang akan dicapai. Kinerja tenaga penjualan ditunjukkan dengan efektivitas aktivitas penjualan yang dilakukan oleh tenaga penjualan. Intensitas tenaga penjualan semakin efektif dapat membantu tenaga penjualan menyelesaikan tugas dan tanggung jawabnya sesuai dengan target penjualan. Intensitas aktivitas tenaga penjualan yang semakin efektif akan membantu tenaga penjualan untuk dapat menyelesaikan setiap tugas dan tanggung jawabnya sesuai dengan target penjualan. Dari uraian di atas diajukan hipotesis:

H3: Ada pengaruh positif efektivitas kegiatan terhadap kinerja pemasaran tenaga penjualan

\section{Hubungan Kompetensi Teknik Pen- jualan Terhadap Kinerja Pemasaran Tenaga Penjualan}

Keahlian mempermudah dalam membentuk suatu pemahaman dan pelaksanaan hubungan strategi antara perusahaan dengan pelanggannya. Oleh karena itu, tenaga penjualan yang memiliki keahlian dalam aktivitas penjualan yang baik dapat memberikan kontribusi positif bagi kondisi perusahaan agar tetap bertahan dan menghasilkan keuntungan bagi perusahaan. Temuan penelitian Baldauf, et al., (2001) bahwa kemampuan menjual memiliki pengaruh yang positif terhadap kinerja tenaga penjualan. Atas dasar uraian di atas dapat diajukan hipotesis:

H4: Ada pengaruh positif kompetensi teknik tenaga penjualan terhadap kinerja pemasaran tenaga penjual.

Berdasarkan telaah pustaka di atas dapat dibuat model empirik Gambar 1.

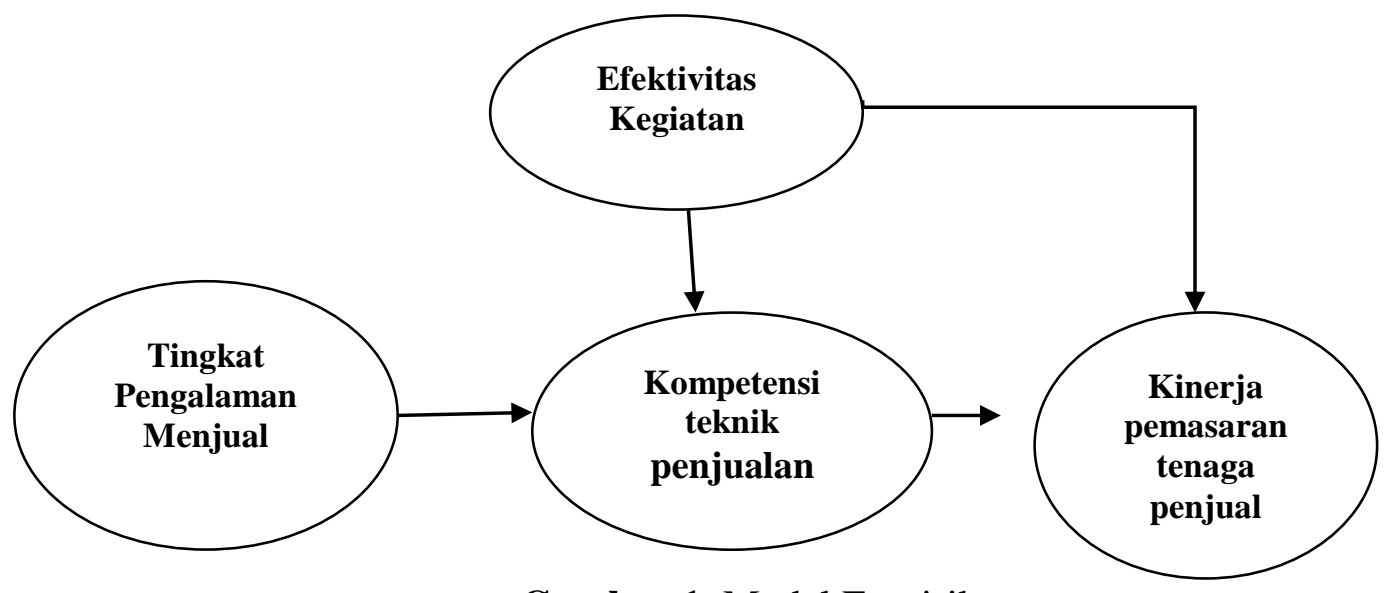

Gambar 1. Model Empirik 


\section{METODE PENELITIAN}

\section{Populasi dan sampel}

Populasi merupakan elemen-elemen yang memiliki satu atau lebih atribut yang menjadi tujuan (Arikunto, 2006). Populasi adalah wilayah generalisasi yang terdiri atas obyek/subyek yang mempunyai kualitas dan karakteristik tertentu yang ditetapkan peneliti kemudian ditarik kesimpulannya. Populasi yang dipilih dalam penelitian ini adalah tenaga penjual pada UKM pakaian jadi di kota Semarang sejumlah 150 responden.

Sampel ialah bagian populasi yang memiliki karakteristik sama dan mewakili populasi. Penentuan jumlah sampel digunakan untuk menginterpretasikan hasil, sesuai dengan alat analisis yang digunakan yaitu Structural Equation Modelling (SEM) maka penentuan jumlah sampel yang representative adalah tergantung pada jumlah indikator dikali 5 sampai 10 (Ferdinand, 2006). Jumlah sampel untuk penelitian adalah: sampel minimum $=$ jumlah indikator $\times 5=16 \times 5$ $=80$ responden. Sampel maksimum $=$ Jumlah indikator x $10=16 \times 100=160$ responden.

Sedangkan jumlah sampel yang digunakan dalam penelitian ini sebanyak 100 tenaga penjualan, yaitu diperoleh dari: jumlah sampel $=$ jumlah indikator $\mathrm{x} 6=16$ $\mathrm{x} 6=96$ dibulatkan menjadi 100 responden.

\section{Jenis data dan Sumber Data}

Pengumpulan data dilakukan dengan daftar pertanyaan (kuesioner) yang dipersiapkan terlebih dahulu. Kuesioner berisi pertanyaan-pertanyaan bagaimana tingkat pengalaman menjual, kompetensi teknik berpengaruh terhadap kompetensi teknik, dan efektivitas kegiatan tenaga penjualan, kompetensi teknik berpengaruh terhadap kinerja tenaga penjualan.

\section{Definisi Operasional dan Indikator}

Definisi operasional variabel dan indikatornya dijabarkan pada Tabel 1 .

\section{HASIL DAN PEMBAHASAN}

\section{Analisis data}

Analisis data menggunakan AMOS versi 16.0. Hasil pengolahan data terlihat pada Tabel 2. Tabel 2, menunjukkan bahwa model ini sesuai dengan data atau fit terhadap data yang digunakan, tingkat signifikansi $(\mathrm{P})$ terhadap chi-square model sebesar $(65,47)$, indeks TLI, CMIN/DF, GFI, AGFI dan RMSEA berada dalam rentang nilai yang diharapkan. Dengan demikian uji hipotesis full model menunjukkan model sesuai dengan data atau fit terhadap data yang digunakan dalam penelitian.

Hasil pengukuran memenuhi kriteria goodness of fit. Selanjutnya, berdasarkan model fit maka dilakukan pengujian terhadap empat hipotesis yang diajukan. Nilai-nilai koefisien regresi hubungan kausalitas dan nilai t hitungnya terlihat dalam nilai $\mathrm{CR}$ (critical ratio), terlihat pada Tabel 3. 
Tabel 1. Definisi operasional dan indikator

\begin{tabular}{|c|c|c|}
\hline Variabel & Konseptual & Indikator \\
\hline Kinerja pemasaran & $\begin{array}{l}\text { Ukuran prestasi dari aktivitas } \\
\text { pemasaran secara menyeluruh dari } \\
\text { sebuah organisasi. }\end{array}$ & $\begin{array}{l}\text { - Volume penjualan } \\
\text { - Jumlah pelanggan } \\
\text { - Pertumbuhan penjualan } \\
\text { - Porsi Pasar } \\
\text { (Sugiyarti, 2017) }\end{array}$ \\
\hline Kompetensi Teknik & $\begin{array}{l}\text { Penguasaan pengetahuan tenaga } \\
\text { penjual tentang produk dan } \\
\text { manfaatnya. }\end{array}$ & $\begin{array}{l}\text { - Pengetahuan } \\
\text { keistimewaan dan } \\
\text { manfaat produk } \\
\text { - Pengetahuan proses } \\
\text { penyampaian produk } \\
\text { - Pengetahuan produk- } \\
\text { produk pesaing } \\
\text { (Rentz, et al. } 2002 \text { ) }\end{array}$ \\
\hline $\begin{array}{l}\text { Tingkat pengalaman } \\
\text { menjual }\end{array}$ & $\begin{array}{l}\text { Tingkat pengalaman menyesuai- } \\
\text { kan diri dalam proses penjualan. }\end{array}$ & $\begin{array}{l}\text { - Pengalaman adaptive } \\
\text { selling dalam proses } \\
\text { penjualan } \\
\text { - Pengalaman gagal } \\
\text { dalam menjual } \\
\text { - Pengalaman dalam } \\
\text { memodifikasi presentasi } \\
\text { penjualan } \\
\text { (Kohli, 1998) }\end{array}$ \\
\hline Efektivitas kegiatan & $\begin{array}{l}\text { Kecepatan dan ketepatan kegiatan } \\
\text { Tas mencari informasi tentang } \\
\text { Pelanggan. }\end{array}$ & $\begin{array}{l}\text { - Kecepatan dan } \\
\text { ketepatan dalam } \\
\text { kegiatan } \\
\text { - Efektif dalam kegiatan } \\
\text { melakukan kunjungan } \\
\text { ke konsumen } \\
\text { (Nuryakin et.,al, 2018) }\end{array}$ \\
\hline
\end{tabular}

Tabel 2. Goodness of Fit Index Modified Structural Equation Model

\begin{tabular}{c|l|c|c|l}
\hline No & Goodness of fit index & Cut of value & Hasil analisis & Evaluasi model \\
\hline 1 & $X^{2}-$ Chi-Square & $<136,57$ & 122,47 & Baik \\
\hline 2 & Signif.Prob & $\geq 0,05$ & 0,07 & Baik \\
\hline 3 & CMIN / DF & $\leq 2.00$ & 1,75 & Baik \\
\hline 4 & CFI & $\geq 0,90$ & 0,96 & Baik \\
\hline 5 & GFI & $\geq 0,90$ & 0,94 & Baik \\
\hline 6 & AGFI & $\geq 0.90$ & 0,93 & Baik \\
\hline 7 & TLI & $\geq 0.95$ & 0,98 & Baik \\
\hline 8 & RMSEA & $\geq 0,08$ & 0,18 & Baik \\
\hline
\end{tabular}

Sumber : data primer yang diolah, 2018 
Tabel 3. Hasil perhitungan Analisis SEM dan pengujian hipotesis

\begin{tabular}{l|l|l|c|c|c|c}
\multicolumn{7}{c}{ Regression Weights: (Group number 1 - Default model) } \\
\hline & & & Estimate & S.E. & C.R. & P \\
\hline Kompetensi teknik & $<---$ & Tingkat pengalaman menjual & 0,308 & 0,261 & 2,133 & 0,032 \\
\hline Kompetensi teknik & $<---$ & Efektivitas kegiatan & 0,975 & 0,388 & 2,471 & 0,011 \\
\hline Kinerja pemasaran & $<---$ & Efektivitas kegiatan & 0,461 & 0,354 & 2,212 & 0,015 \\
\hline Kinerja pemasaran & $<---$ & Kompetensi teknik & 0,751 & 0,387 & 2,164 & 0,031 \\
\hline
\end{tabular}

\section{Pembahasan}

Hipotesis 1 semakin tinggi tingkat pengalaman menjual maka semakin tinggi kompetensi teknik tenaga penjualan. Atas dasar pengolahan data Tabel 3, diketahui bahwa nilai CR sebesar 2,133 di atas 1,96 syarat dari nilai $\mathrm{CR}$. Sedangkan nilai $\mathrm{P}$ 0,032 kurang dari 0,05 syarat dari nilai P. Dengan demikian dapat dikatakan bahwa hipotesis I dapat diterima. Temuan ini sejalan dengan Rentz, et al. (2002) dan Kohli (1998) ada pengaruh positif dan signifikan antara tingkat pengalaman menjual dengan kompetensi teknik. Dari pengolahan data disimpulkan bahwa indikator pengalaman dalam memodifikasi presentasi penjualan adalah indikator paling dominan dari tingkat pengalaman tenaga penjualan. Hal ini mengindikasikan bahwa tenaga penjualan memiliki banyak pengalaman dalam memodifikasi presentasi penjualan akan meningkatkan kompetensi teknik tenaga penjualan.

Hipotesis 2 semakin tinggi efektivitas kegiatan maka semakin tinggi kompetensi teknik tenaga penjualan. Berdasar pengolahan data Tabel 3, diketahui bahwa nilai CR sebesar 2,471 di atas 1,96 syarat dari nilai CR. Nilai P 0,01 kurang dari 0,05 syarat dari nilai $\mathrm{P}$. Oleh karena itu hipotesis 2 dapat diterima. Temuan ini sejalan dengan (Baldauf, et al., 2001). Hasil pengolahan data menunjukkan bahwa indikator pengetahuan keistimewaan dan manfaat produk, pengetahuan produk-produk pesaing adalah indikator yang paling dominan dalam kompetensi teknik tenaga penjualan.
Hal ini memberikan penjelasan bahwa pengetahuan keistimewaan dan manfaat produk, serta indikator pengetahuan produk-produk pesaing akan dapat membentuk efektivitas kegiatan/aktivitas tenaga penjualan.

Hipotesis 3 semakin tinggi efektivitas kegiatan maka semakin tinggi kinerja pemasaran tenaga penjualan. Berdasar pengolahan data Tabel 3, diketahui bahwa nilai CR sebesar 2,212 di atas 1,96 syarat dari nilai CR. Nilai P 0,015 kurang dari 0,05 syarat dari nilai $\mathrm{P}$. Oleh karena itu hipotesis 3 diterima. Temuan ini sejalan dengan Nuryakin et al., (2018) dan (Baldauf, et al., 2001). Hasil analisis SEM diketahui bahwa indikator reflektif kegiatan melakukan kunjungan ke konsumen merupakan indikator yang paling dominan dari efektivitas kegiatan tenaga penjualan. Hal ini mengindikasikan bahwa adanya kegiatan melakukan kunjungan ke konsumen yang efektif akan dapat meningkatkan kinerja pemasaran tenaga penjualan.

Hipotesis 4 semakin tinggi kompetensi teknik tenaga penjualan maka semakin tinggi kinerja pemasaran. Berdasar pengolahan data Tabel 3, diketahui bahwa nilai CR sebesar 2,164 di atas 1,96 syarat dari nilai CR. Nilai P 0,031 kurang dari 0,05 . Oleh karena itu hipotesis 4 diterima. Temuan ini sejalan dengan Liu \& Leach (2001). Berdasarkan pengolahan data bahwa indikator pengetahuan keistimewaan dan manfaat produk, dan indikator pengetahuan produk-produk pesaing merupakan indikator yang paling 
dominan dari kompetensi teknik tenaga penjualan. Hal ini memberikan pemahaman bahwa dengan memiliki pengetahuan tentang keistimewaan dan manfaat produk, dan memiliki pengetahuan yang baik tentang produk-produk pesaing maka dapat meningkatkan kinerja tenaga penjualan.

\section{Kesimpulan}

Penelitian ini berfungsi untuk menjawab bagaimana kompetensi teknik tenaga penjualan dan kinerja pemasaran tenaga penjualan dapat ditingkatkan dilihat tingkat pengalaman menjual, efektivitas kegiatan. Berdasarkan hasil penelitian yang dilaksanakan ditemukan bahwa ada pengaruh positif dan signifikan antara tingkat pengalaman menjual dan efektivitas kegiatan terhadap kompetensi teknik penjualan dan pengaruh positif dan signifikan antara efektivitas kegiatan dan kompetensi teknik terhadap kinerja pemasaran tenaga penjualan.

\section{Implikasi Manajerial}

Perusahaan sebaiknya dalam menentukan target penjualan mempertimbangkan kemampuan yang dimiliki oleh tenaga penjualan, sehingga disarankan untuk menghindari penentuan target penjualan terlalu tinggi di luar kemampuan dari tenaga penjualan.

Perusahaan selalu menanamkan pengertian kepada seluruh tenaga penjualan bahwa pelaksanaan secara rutin dengan evaluasi periodik setengah bulanan tentang kemampuan untuk meyakinkan konsumen membeli produk kita adalah suatu keberhasilan yang dapat diraih oleh tenaga penjualan. Sehingga tenaga penjual harus berpengalaman dalam presentasi untuk meyakinkan pelanggan.

\section{Implikasi Teoritis}

Studi ini mendukung secara empiris penelitian Rentz, et al. (2002) dan Kohli (1998) bahwa penelitian pengaruh tingkat pengalaman menjual tenaga penjualan terhadap kompetensi teknik tenaga penjualan adalah telah mendapatkan justifikasi dukungan secara empirik, sehingga hasil penelitian rujukan dan penelitian ini dapat diaplikasikan pada persoalan-persoalan yang sama.

Studi ini mendukung secara empiris penelitian Rentz (2002), Baldauf et al. (2001), Sugiyarti (2017), Nuryakin et al. (2018) dan Ardyan (2018) bahwa penelitian ini mempunyai pengaruh positif kompetensi teknik dengan kinerja pemasaran tenaga penjualan adalah telah mendapatkan justifikasi dukungan secara empirik, sehingga hasil penelitian rujukan dan penelitian ini dapat diaplikasikan pada persoalan-persoalan yang sama.

\section{DAFTAR PUSTAKA}

Ardyan, E., \& Sugiyarti, G. (2018). The Influence of E-CRM Capability And Co-Information Sharing Activity on Product Competitiveness And Marketing Performance of Small And Medium-Sized Enterprises. International Journal of Electronic Customer Relationship Management, 11(2), 158-178.

Baldauf, A., Cravens, D. W., \& Piercy, N. F. (2001). Examining business strategy, sales management, and salesperson antecedents of sales organization effectiveness. Journal of Personal Selling \& Sales Management, 21(2), 109-122.

Ferdinand, A. (2000). Manajemen Pemasaran. Sebuah Pendekatan Strategy. Research Paper Serie. No. 01 Program Magister Manajemen Universitas Diponegoro.

Homburg, C., Artz, M., \& Wieseke, J. (2012). Marketing Performance Measurement Systems: Does Comprehensiveness Really Improve Performance? Journal of Marketing, 76(3), 56-77. 
Kohli, A.K., Shervani,T.A. \& Challagalla, G.N. (1998). Learning and Performance Orientation of Salespeople: The Role of Supervisors. Journal of Marketing Research, XXXV, 267- 274.

Kristina,C (2006). Pola Bekerja Cerdas Tenaga Penjualan (Studi empiris Tenaga Penjualan pada Pedagang Besar Farmasi di Kota Semarang). Jurnal Sains Pemasaran Indonesia, $V(1), 63-86$.

Lamberti, L. \& Noci, G. (2010). Marketing strategy and marketing performance measurement system: Exploring the relationship. European Management Journal, 28(2), 139-152.

Liu, A. H., \& Leach, M. P. (2001). Developing loyal customers with a value-adding sales force: Examining customer satisfaction and the perceived credibility of consultative salespeople. Journal of Personal Selling \& Sales Management, 21(2), 147-156.

Narver, J. C., \& Slater , S. F. (1990). The Effect of Market Orientation on Business Profitability. Journal of Marketing, 20-35.

Nuryakin \& Sugiyarti, G. (2018). Developing customer orientation to enhancing salesperson performance. Journal of Business and Retail Management Research (JBRMR), 12(2), 144-151.

Rentz, J. O., Shepherd, C. D., Tashchian, A., Dabholkar, P. A., \& Ladd, R. T. (2002). A Measuren of Selling Skill: Scale Development and Validation. Journal of Personal Selling and Sales Management, 22(1), 13-21.

Sengupta, S., Krapfel, R. E., \& Pusateri, M. A. (2000). An empirical investigation of key account salesperson effectiveness. Journal of Personal Selling \& Sales Management, 20(4), 253-261.
Siagian, S. P. (2008). Manajemen Sumber Daya Manusia. Jakarta: Bumi Aksara.

Sugiyarti, G. \& Ardyan, E. (2017). Market Sensing Capability and Product Innovation Advantages in Emerging Markets: The Case of Market Entry Quality and Marketing Performance of Batik Industry in Indonesia. DLSU Business \& Economics Review 27(1): 1-12.

Sugiyarti, G. (2015). Creation Marketing Capabilities as Antecedents For Success Marketing Performance. Journal of Research in Marketing Volume, 5(1), 321-329.

Suharsimi, A. (2006). Prosedur Penelitian Suatu Pendekatan Praktik. Jakarta: Rineka Cipta. 